\title{
建築再生における建材流通拠点に関する研究 ホームセンター型建材流通に関する考察
}

\section{THE DISTRIBUTION OF BUILDING COMPONENTS IN THE RENOVATION MARKET} Study on distributing components by the home improvement center

\section{佐藤考一 ${ }^{*}$, 松村秀一 ${ }^{* *}$, 遠藤 和 義 ${ }^{* * *}$, 角田 誠 ${ }^{* * * *}$ \\ Kouichi SATO, Shuichi MATSUMURA, Kazuyoshi ENDO and Makoto TSUNODA}

\begin{abstract}
This paper aims to discuss the distribution of building materials by home improvement centers. Based on the analysis of Commercial Statistics and the questionnaire survey for them, the following three points are clarified: Firstly, the market of them is growing up and dispersing stores more. Secondly, their stores are categorized to two types. One is used by general consumers and the other is by small constructors. And finally, many of the latter are flagship stores built in suburbs. They have more skilled stuffs and supply general consumers better services for renovating their houses and small constructors better building materials.
\end{abstract}

\section{Keywords : Distribution of Building Materials, Renovation Market, Home Improvement Center, Building Components and Reform of houses 建材流通, 住宅再生市場, ホームセンター, 住宅部品, 住宅リフォーム}

\section{1. はじめに}

近年の新築住宅市場は 120 万戸前後を推移しているが、長期的に はさらに縮小すると予想される。日本の総人口は 2005 年から減少に 転じたためである。その一方で、小世帯化・高齢化の進行は既存住宅 の改修需要を増加させると考えられる。

多くの場合、こうした工事の発注者は、住宅購入経験者であること から、建材・住宅部品に関する知識が豊富で改善要求も具体的である。 つまり、住宅再生市場では、新築住宅市場よりもきめ細かなカスタマ イゼーションが求められ、工事業者は多様な建材の小口・当用買いが 必要になる。また、新築工事でも、基礎工事や金物工事などの零細個 人企業への外注が増え、同様の需要が生まれている。しかし、卸問屋 から販売店を経るこれまでの建材流通チャネルは、新築市場に対寸る 大量販売を前提としており、再生市場の需要との矛盾点も少なくない。 現在、日本では 320 社ほどの企業によって、4000 店舗を越えるホ 一ムセンターが営まれている。これらは建材に関する唯一の大型店舗 である注1)。そのため、これらを拠点とした流通チャネルが、住宅再 生市場に適した建材流通を実現する可能性は大きい。実際、近年のホ 一ムセンターの顧客層は、一般消費者だけでなく、建築工事業者にも 広がりを見せており、その業務範囲も物販サービスに止まらず、工事 サービス、メンテナンスサービス等にまで拡大し始めている。

\section{2. 研究目的}

本研究の目的は、今後の建築生産に求められる新たな流通システム として、ホームセンター型建材流通の将来性について検討寸ることに ある。流通機能は、生産と消費の間に生じる隔たりを架橋することに ある。その隔たりは所有、空間、時間、情報の四つに分けられ、商学 分野ではそれぞれをロットサイズ、市場分散化、配達時間、品揃えに よって評価する注 2)。本研究では、ホームセンターと工事業者の間の 空間と情報の隔たりに着目し、市場分散化と品揃えの特性を明らかに する。さらに、サービス業務展開の実態把握に基づき、今後の建材流 通チャネルとしてのポテンシャルについても検討する。

\section{3. 研究方法}

ホームセンター市場全体を把握できる唯一の統計資料が「商業統計 表一業態別集計」である。市場分散化の分析はこの資料に基づいて行 う。この統計調査は 1952 年から $2 \sim 3$ 年に 1 回の頻度で実施されて いる。ホームセンターが集計単位として登場したのは 2002 年統計で あり、これ以降は事業所 (店舗) 数などを都道府県別に把握できる。 なお、商業統計におけるホームセンターとは、表 1 に示すように、住 関連専門スーパーの中で荒物や農耕用品を扱う店舗を指寸注3)。

ホームセンター店舗の品揃え並びにサービス業務の分析は郵送ア

\footnotetext{
* A/E WORKS 博士 (工学)

** 東京大学大学院工学系研究科 教授. 工博

*** 工学院大学建築学科 教授・博士 (工学)

**** 首都大学東京都市環境学部建築都市コース 教授・博士 (工学) 
ンケート調查に基づいて行う注4)。概要は表 2 に示す通りである。調 查対象には日本 DIY 協会のホームページが紹介するリフォーム取扱 店 541 店舗（39 社）の中から 342 店舗（32 社）を選定した注5)。回 答率はそれぞれ $23 \%$ と $28 \%$ である。なお、ホームセンターの今後の 経営戦略等に関する知見を補足するため、ヒアリング調查を 9 社に対 して実施した注6)。

表 1 商業統計における「ホームセンター」の定義

\begin{tabular}{|c|c|}
\hline 業態 & 条件 \\
\hline ホームセンター & \begin{tabular}{|l} 
・住関連専門スーパーで次の条件を満たすもの \\
取扱商品：(59E)荒物・金物+(602)農耕用品が $0 \sim 70 \%$
\end{tabular} \\
\hline $\begin{array}{l}\text { 住関連 } \\
\text { 専門スーパー }\end{array}$ & $\begin{array}{l}\text { (1)セルフサービス方式，(2)売場面積 : } 250 \mathrm{~m}^{2} \text { 以上 } \\
\text { (3)取扱商品 : 住*が } 70 \% \text { 以上 } \\
\text { *(58)自動車+(59)家具・じゅう器・機械器具+(60)その他 }\end{array}$ \\
\hline
\end{tabular}
備考: 括弧内の数字は日本標準产業分類の分類番号を示寸。

表 2 ホームセンターに対する郵送アンケート調查の概要

(1) 調查方法

\begin{tabular}{c|l}
\hline 調查対象 & $\begin{array}{l}\text { (社)日本 DIY 協会の加盟企業のリフォーム取扱店 } \\
\text { (1)店舗 } 342 \text { 件：「展示コーナー」か「専用受付相談空口」を有する } \\
\text { (2)本社 } 32 \text { 社：(1)に該当する店舗を展開している企業 }\end{array}$ \\
\hline 調査期間 & 2006 年 10 月 \\
\hline 調查項目 & $\begin{array}{l}\text { A)店舗・顧客等の概要，B)物販業務，C)流通業務，D)工事業務, } \\
\text { E)その他 }\end{array}$ \\
\hline 回収状況 & (1) 80 件 $(23 \%) 、(2) 11$ 件 $(28 \%)$ \\
\hline
\end{tabular}

(2) 店舗アンケートの地方別回収状況

\begin{tabular}{c|r|r|c|r|r|r|r|r|r}
\hline 地方 & 北海道 & 東北 & 関東 & $\begin{array}{l}\text { 北陸 } \\
\text { 甲信 }\end{array}$ & 東海 & 近畿 & 中国 & 四国 & $\begin{array}{c}\text { 九州 } \\
\text { 沖縄 }\end{array}$ \\
\hline 配布内訳 & $3.8 \%$ & $7.0 \%$ & $41.2 \%$ & $6.1 \%$ & $8.5 \%$ & $20.8 \%$ & $4.4 \%$ & $5.6 \%$ & $2.6 \%$ \\
\hline 回收内訳 & $0 \%$ & $6.3 \%$ & $48.8 \%$ & $0 \%$ & $6.3 \%$ & $26.3 \%$ & $1.3 \%$ & $11.3 \%$ & $0 \%$ \\
\hline
\end{tabular}

(3) 店舗アンケートの都市規模別回収状況

\begin{tabular}{c|c|c|c|c|c|c|c}
\hline 都市規模 & 100 万人以上 & $\sim 50$ 万人 & $\sim 20$ 万人 & $\sim 10$ 万人 & $\sim 5$ 万人 & $\sim 2$ 万人 & 2 万人未满 \\
\hline \hline 配布内訳 & $16.4 \%$ & $12.9 \%$ & $26.3 \%$ & $20.8 \%$ & $16.7 \%$ & $6.1 \%$ & $0.9 \%$ \\
\hline 回収内訳 & $22.5 \%$ & $16.3 \%$ & $25.0 \%$ & $21.3 \%$ & $10.0 \%$ & $3.8 \%$ & $1.3 \%$ \\
\hline
\end{tabular}

\section{4. ホームセンターの市場分散化の特性}

(1) 大型店舗市場の中でのホームセンター

商業統計によれば、1985 年以降、日本の小売店舗数は減少し続け ており、小売業全体として大型店舗への集中が進行している。表 3 は 2004 年における大型店舗市場の概況である注 7)。専門スーパーの 総販売額は大型店舗市場の約 6 割を占める。過去 5 年間に、その額 は $4 \%$ ほど増加したが、その中でもホームセンターと衣料品スーパー の成長は著しい注 8)。現在、ホームセンターが大型店舗市場に占める 割合は販売額の $6.7 \%$ 、売場面積の $14.2 \%$ である。過去 5 年間におけ る店舗数の平均年間増加率は $12.7 \%$ になる。

\section{(2) 小売店舗密度とその規定要因}

商学分野では「小売店舗密度」という指標によって市場分散化を測 る。小売店舗密度とは人口当たりの小売店舗数である。その逆数は店 舗当たりの人口を示す。この值を人口密度で除すと、店舗当たりの地 域面積が得られ、商圈半径も算出できる注 9)。つまり、小売店舗密度 に基づき、当該業種の店舗に関する様々な商圈水準が示される。

小売店舗密度の規定要因は、(1)小売業者の販売行動、(2)都市化の程 度、(3)消費者の買物行動の三つに整理できる注 10)。小売業者の販売行 動は、品揃えや店舗規模に代表される小売ミックス (顧客誘引方法) によって規定され、都市化の程度は、人口密度やモータリゼーション の進行状況等によって規定される。

消費者の買物行動が及ぼす影響は、一般的に、商品を「最寄品」「買 回り品」「専門品」の 3 種類に分けて分析される注 11$) 。$ 最寄品とは、 食料品など、消費者の探索性行と銘柄固執が小さな商品であり、身近 な店舗で購入される傾向が強い。買回り品とは、家電製品など、銘柄 固執は小さいが探索性行の大きな商品である。消費者は商品比較のた めにある程度の努力をするので、買物行動エリアが広くなる。専門品 とは、ブランド品など、銘柄固執が大きな商品である。消費者は購入 努力を惜しまないので、買物行動エリアはさらに広くなる。

つまり、主力商品が最寄品の小売業では、店舗が消費者に近いほど 販売チャンスが増えるため、多店舗展開が促進されて小売店舗密度は 大きくなる。買回り品中心の小売業も、基本的には店舗数の増加が販

表 3 大型店舗の市場特性の比較

\begin{tabular}{|c|c|c|c|c|c|c|c|c|c|c|c|c|c|c|c|c|}
\hline \multirow[b]{2}{*}{ 年 } & \multirow{2}{*}{\multicolumn{2}{|c|}{ 項目 }} & \multicolumn{3}{|c|}{ 総計 } & \multirow{2}{*}{\begin{tabular}{|l|} 
店舗数 \\
平均年 \\
間増加 \\
率*
\end{tabular}} & \multicolumn{4}{|c|}{ 都道府県の立地密度(佔/ $\left.100 \mathrm{k} \mathrm{m} \mathrm{m}^{2}\right)$} & \multicolumn{3}{|c|}{ 回帰結果 } & \multicolumn{3}{|c|}{ 商圈水準の都道府県平均 } \\
\hline & & & 店舗数 & $\begin{array}{l}\text { 年間売 } \\
\text { 上総額 } \\
\text { (兆円) }\end{array}$ & $\begin{array}{l}\text { 総売場 } \\
\text { 面積 } \\
\left(\text { 万 }{ }^{2}\right)\end{array}$ & & 平均 & 最小 & 最大 & $\begin{array}{l}\text { 標隻 } \\
\text { 扁差 }\end{array}$ & $\mid \begin{array}{c}\text { 勾配 } \\
\text { (店/万人) }\end{array}$ & $\mid$\begin{tabular}{|} 
定数項 \\
佔/ $/ 100 \mathrm{~km} m$
\end{tabular} & $\mathrm{R}^{2}$ & $\underset{\text { (万人/店) }}{\text { 人口 }}$ & $\left|\begin{array}{r}\text { 面積 } * * \\
\left(100 \mathrm{k} \mathrm{m}^{2} / \text { 店 }\right.\end{array}\right|$ & $\begin{array}{l}\text { 半径 } \\
(\mathrm{km})\end{array}$ \\
\hline 1999 & \multicolumn{2}{|c|}{ ホームセンター } & 2911 & 2.40 & 525 & - & 1.2 & 0.2 & 5.7 & 1.1 & 0.09 & 0.58 & 0.88 & 11.0 & 3.29 & 9.1 \\
\hline \multirow{3}{*}{2004} & \multicolumn{2}{|c|}{ ホームセンター } & 4764 & 3.14 & 953 & $12.7 \%$ & 1.9 & 0.3 & 7.9 & 1.8 & 0.15 & 0.96 & 0.88 & 6.6 & 1.95 & 7.0 \\
\hline & \multicolumn{2}{|c|}{ 内訳(1)立地密度 3 以上 } & 3233 & 1.85 & 643 & $10.6 \%$ & 5.1 & 2.9 & 7.9 & 2.0 & 0.11 & 2.70 & 0.91 & 9.5 & 0.53 & 3.6 \\
\hline & \multicolumn{2}{|c|}{ 内訳(2)立地密度 3 未満 } & 1531 & 1.29 & 311 & $18.2 \%$ & 1.2 & 0.3 & 2.4 & 0.5 & 0.29 & 0.45 & 0.63 & 3.4 & 1.74 & 6.6 \\
\hline \multirow{5}{*}{2004} & \multicolumn{2}{|r|}{ 百貨店 } & 308 & 8.00 & 647 & $-4.4 \%$ & 0.2 & 0.0 & 2.0 & 0.3 & 0.03 & 0.02 & 0.93 & 36.0 & 10.64 & 16.3 \\
\hline & \multicolumn{2}{|c|}{ 総合スーパー } & 1675 & 8.41 & 1519 & $0.1 \%$ & 0.8 & 0.1 & 6.0 & 1.3 & 0.11 & 0.11 & 0.98 & 9.1 & 2.69 & 8.2 \\
\hline & \multirow{3}{*}{$\begin{array}{l}\text { 専門 } \\
\text { スーパー }\end{array}$} & 食料品 & 18485 & 17.05 & 1825 & $-0.2 \%$ & 8.5 & 1.1 & 57.6 & 11.7 & 1.03 & 1.83 & 0.99 & 1.0 & 0.29 & 2.7 \\
\hline & & 衣料品 & 5991 & 1.54 & 416 & $5.1 \%$ & 2.5 & 0.3 & 12.7 & 2.7 & 0.21 & 1.16 & 0.78 & 4.8 & 1.41 & 5.9 \\
\hline & & 住関連*** & 6980 & 2.37 & 546 & $0.0 \%$ & 3.0 & 0.4 & 19.7 & 3.8 & 0.34 & 0.93 & 0.88 & 3.1 & 0.91 & 4.8 \\
\hline \multirow{2}{*}{2004} & \multicolumn{2}{|c|}{ 家電量販店 } & 4412 & 5.52 & 480 & $-4.8 \%$ & 2.3 & 0.2 & 21.4 & 4.0 & 0.35 & -0.03 & 0.97 & 2.8 & 0.84 & 4.6 \\
\hline & \multicolumn{2}{|c|}{ 家具量販店 } & 1443 & 1.01 & 335 & \begin{tabular}{|l|}
$-7.3 \%$ \\
\end{tabular} & 0.7 & 0.1 & 6.7 & 1.3 & 0.11 & 0.01 & 0.96 & 9.0 & 2.67 & 8.2 \\
\hline
\end{tabular}

*** ホームセンター以外の住関連スーパー 
売チャンスの拡大につながるが、消費者の買物行動エリアは広いので、 小売店舗密度は最寄品の小売業ほど大きくならない。一方、専門品の 小売業は、ブランドイメージ保持等の理由で立地が限定されることも 多く、積極的に店舗数を増やすとは限らない。

\section{(3) ホームセンターの商圏水準}

1999 年から 2004 年までにホームセンターの総店舗数は約 1900 店 増加し、立地密度は 1.2 店 $/ 100 \mathrm{k} \mathrm{m}^{2}$ から 1.9 店 $/ 100 \mathrm{k} \mathrm{m}^{2}$ へ上上昇し た。図 1 は、人口密度を説明変数として、47 都道府県のホームセン ター立地密度の分布を示している。その回帰式の勾配はホームセンタ 一の全国的な小売店舗密度を表す。2004 年時点の小売店舗密度は 0.15 であり、商圈人口は 6.6 万人/店、商圈半径は $7.0 \mathrm{~km}$ になる。

ところで、図 1 を見ると立地密度 3 付近を境に小売店舗密度が低下 している。その值は、立地密度 3 未満の 38 道府県では 0.29 である

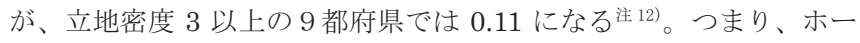
ムセンター市場は、市場分散化の観点から二つのグループに分けられ、 店舗当たり半径 $6.6 \mathrm{~km}$ に 3.5 万人の商圈人口を抱える低密度市場と 半径 $3.6 \mathrm{~km}$ に 9.5 万人を抱える高密度市場とが存在している。

\section{(4) 市場分散化に関する考察}

現在のホームセンター市場に認められる大きな特徴は、分散化の異 なる二つのグループが併存する点にある。前述したように、小売店舗 密度は小売業者の販売行動、都市化の程度、消費者の買物行動によっ て規定されるが、さらに当該市場の成熟度からも影響を受ける。しか し、単一の業態を対象とした場合、小売業者の販売行動に大きな違い はないと見なせる。従って、ホームセンター市場に二つのグループを 生み出している主要因は、これを除く三つに限定される。

まず、大型店舗の分布は都市化の進行と関係が深いと予想される。 実際、立地密度 3 以上の 9 都府県には可住地率 $50 \%$ 以上かつ宅地率 $10 \%$ 以上という共通性が見られ注 ${ }^{13)} 、 47$ 都道府県を都市化グループ と非都市化グループに分類した既往研究とも概放整合している注 14)。 もし、都市化の程度がホームセンター市場に二つのグループを生み出 寸主要因であるとすれば、他の大型店舗市場にもこうした現象が共通 に見られるはずである。しかし、ホームセンターと同様の小売店舗密 度の低下は、百貨店や総合スーパー等には見られず、衣料品スーパー と住関連スーパーの二つの業態にしか見られない。従って、都市化の 差異がホームセンター市場に二つのグループを生み出している可能 性は低い。

次に、ホームセンターの主力商品が買回り品であることから、消費 者の買物行動がそうした市場現象を生み出している可能性がある。確 かに衣料品スーパーと住関連スーパーも主力商品が買回り品である。 もし、買物行動が主要因であると寸れば、探索性行の強い高額商品を 扱う業態になるほど小売店舗密度の変化は大きいはずである。しかし、 図 2 に示されるように注 ${ }^{15)}$ 、より高額な買回り品を扱っている家電量 販店や家具量販店にはこうした変化は見られず、消費者の買物行動が そうした現象を生み出している可能性も低い。

最後に残された可能性が市場の成熟度の影響である。表 3 の店舗数 年間平均増加率が示寸ように、ホームセンターと衣料品スーパーは市 場成長の過程にある。住関連スーパーの店舗数は安定しているように 見えるが、1999 年から 2002 年かけていったん $24 \%$ 増加しており、 実際の変動は大きい。住関連スーパーには様々なチェーンストアが含 まれるので販売行動は一様ではないが、少なくとも安定した市場では

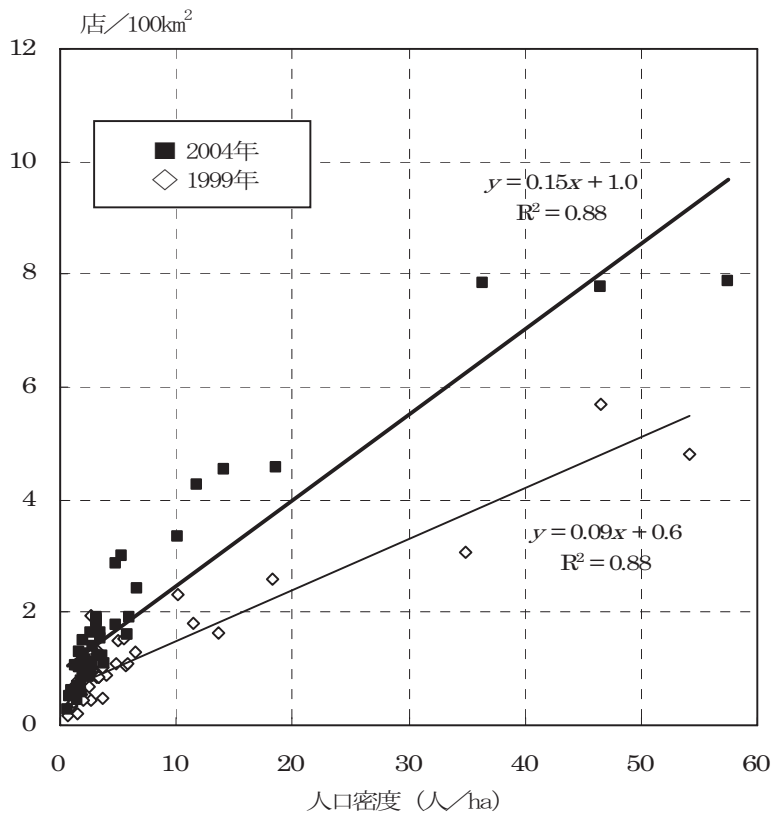

図 1 ホームセンター立地密度分布の推移

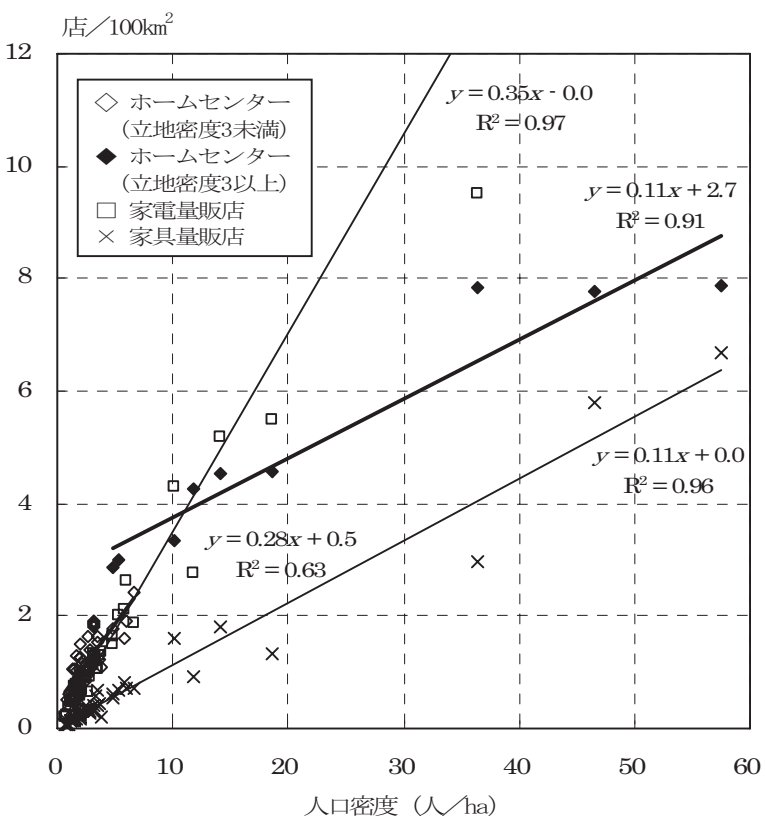

図 2 立地密度分布の比較

ない。一方、小売店舖密度の大きな変化が見られない百貨店、総合ス 一パー、食料品スーパーは店舗数が安定した成熟市場である。家電量 販店と家具量販店は減少傾向にあるが、これらの市場は成長期を終え て調整段階に入っている注 16$)$

以上の検討より、現在のホームセンターの市場分散化は、市場成長 期に現れた一時的局面と考えるのが妥当である。つまり、人口密度の 高い地域では、店舗数が飽和するまでに時間を要することから、市場 の成長過程では小売店舗密度が相対的に低くなる。現時点のホームセ ンター市場には、立地密度 3 近辺を境に店舗数が飽和したグループと 飽和していないグループが混在しているのである。

従って、今後も立地密度 3 以上の都府県では、ホームセンターの店 舗数が増加し続け、全国的な小売店舗密度は 0.15 よりも大きくなる 
と予想される。但し、ホームセンター市場の成長を支えてきた神奈川 と埼玉では、売場面積当たりの売上高が 1999 年から 2004 年にかけ て 4 割ほど減少するなど、店舗の生産性が低下している。そのため、 こうしたエリアの販売行動は、これまでのような積極的な多店舗展開 とは異なる方向に転換される可能性もある。その場合、小売店舗密度 はさほど上昇しないと考えられる。

\section{5. ホームセンターの店舗類型}

\section{(1) アンケート回答店舗の特徵}

商業統計によればホームセンター全体の $37 \%$ が関東地方と近畿地 方に存在する。表 2 に示したように、調查対象としたホームセンター のリフォーム取扱店は $62 \%$ ごこらの地方に集中しており、さらに $56 \%$ は 20 万人以上の都市に立地する。つまり、今回の調查対象の半 数ほどは東京・大阪近郊や地方中核都市の店舗であり、回答が得られ た店舗の所在地は調查票の配布数に対応している。但し、都市規模に ついては、50 万人以上都市の店舗からの回答率がやや高く、その分 だけ 10 万人未満都市の店舗からの回答率が低い。

\section{(2) 一般消費者利用型店舗と建築業者利用型店舗の差異}

近年のホームセンターは一般消費者だけでなく建築業者の顧客が 増加している滥17)。図4 亿示すように、店舗を主な顧客層で分けると、 都市規模が小さくなるほど一般消費者の利用が多い店舗の割合が減 少し、建築業者の利用の多い店舗が増加する傾向が見られる。

ここで前者を「一般消費者利用型店舗」、後者を「建築業者利用型 店舗」と呼び、顧客層に偏りのない店舗を「両方利用型店舗」と呼ぶ。

図 5 はこれらの店舗類型を比較したものである。年間売上高と屋内売 場面積の内訳を見ると、これらが大きな店舖の占める割合は、一般消 費者利用型よりも建築業者利用型の方がやや大きい。各店舗が想定寸 る商圈については、前者の $43 \%$ は $5 \mathrm{~km}$ 未満であるのに対し、後者の $44 \%$ は $7.5 \mathrm{~km}$ 以上である。図 4(2)が示すように建築業者利用型店舗の $60 \%$ は関東地方に集中しているが、前述したように東京・神奈川・ 埼玉・千葉は店舗当たり半径 $3.6 \mathrm{~km}$ に 9.5 万人の商圈人口を抱える 市場である。つまり、建築業者利用型店舗の半数ほどは、その市場水 淮から逸脱した規模を持つことから、高密度市場の中の旗艦店と考え られる。

そうした建築業者利用型店舗の性格は人員配置にもよく現れてい る。図 5(4)が示すように、DIY アドバイザーが店員の $5 \%$ 以上である 店舗は注 ${ }^{18)}$ 、一般消費者利用型では $32 \%$ に止まるが、建築業者利用 型では $48 \%$ に達する。

\section{6. ホームセンターの品揃えの特性 \\ (1) 売上高の内訳}

一般に顧客層に応じて品揃えは変化する。図 6 は「用具・素材」に 関する売上高の内訳を示す注 ${ }^{19)}$ 。最も売上比率が大きい商品は木質材 料 $(21 \%)$ であり、次いで道具・工具 $(14 \%)$ 、建築金物（13\%）が 続く。しかし、一般消費者利用型店舗と建築業者利用型店舗の売上高 を比較しても、後者の方が道具・工具の占める割合がやや大きいもの の、両者の内訳に大きな違いは見られない。

近年のホームセンターは、「資材館」と呼ばれるような建築業者向 け売場を併設する店舗が増えており、こうした売場ではよりグレード の高い木材等が販売されている。今回のアンケート調查ではそうした $\begin{array}{llllll}0 \% & 20 \% & 40 \% & 60 \% & 80 \% & 100 \%\end{array}$

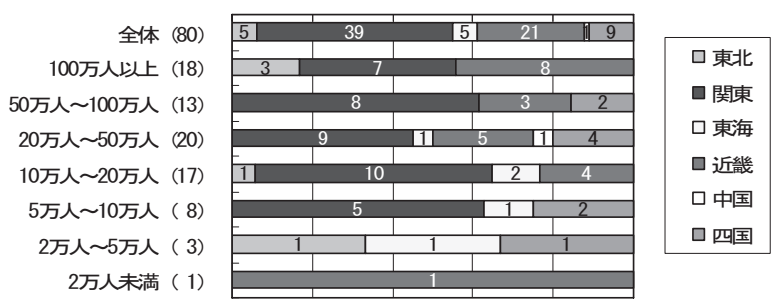

図 3 アンケート回答店舗の都市規模分布と所在地分布

$\begin{array}{llllll}0 \% & 20 \% & 40 \% & 60 \% & 80 \% & 100 \%\end{array}$

全体 (80)

100 万人以上 (18) 50 万人 100万人 (13) 20万人 50万人 (20) 10万人 20万人 (17) 5 万人 10万人 ( 8) 2万人 5万人 (3)

2万人未満 (1)

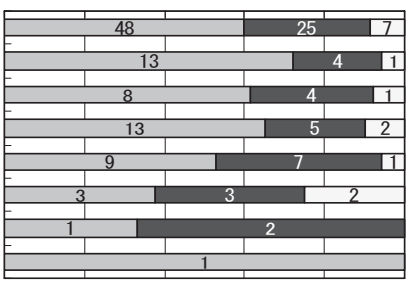
\begin{tabular}{l|} 
口一般绡費者 \\
口建築業者 \\
\hline
\end{tabular} (1) 都市規模別 $\begin{array}{llllll}0 \% & 20 \% & 40 \% & 60 \% & 80 \% & 100 \%\end{array}$

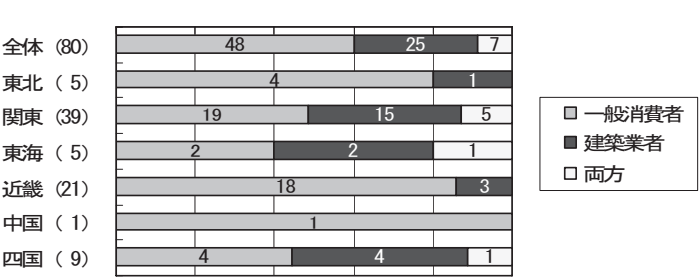

(2) 所在地別

図 4 店舗の主な顧客層

$\begin{array}{llllll}0 \% & 20 \% & 40 \% & 60 \% & 80 \% & 100 \%\end{array}$

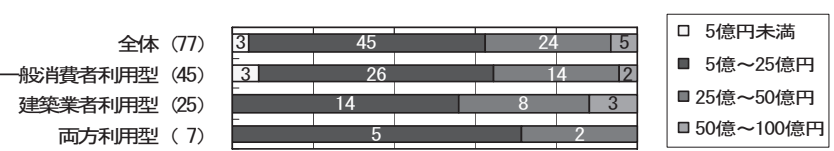

(1) 年間売上高

$\begin{array}{llllll}0 \% & 20 \% & 40 \% & 60 \% & 80 \% & 100 \%\end{array}$

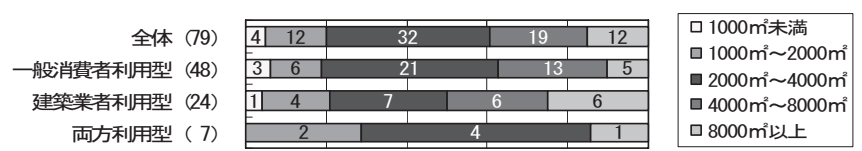

（2）屋内売場面積

$\begin{array}{lllll}0 \% & 20 \% & 40 \% & 60 \% & 80 \%\end{array} \quad 100 \%$

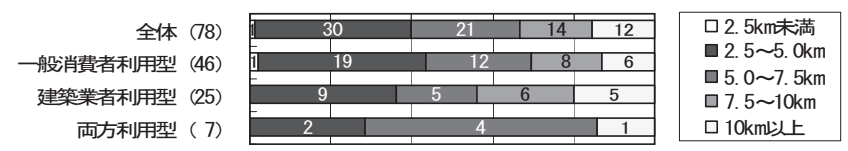

(3) 各店舗が想定する商圈

$\begin{array}{llllll}0 \% & 20 \% & 40 \% & 60 \% & 80 \% & 100 \%\end{array}$

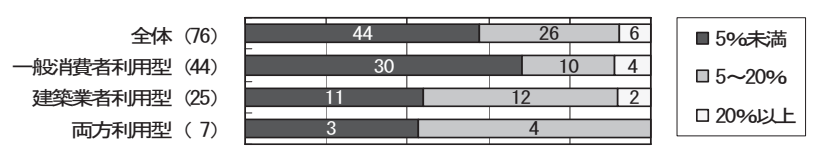

(4) 店員に占める DIY アドバイザーの割合

図 5 ホームセンター店舗類型の特徵 
売場の有無を確認していないが、売上高の内訳を見る限り、主要顧客 層が異なっても通常売場の品揃えが大きく変わることはないと考え られる。

(2) 取扱商品の顧客誘引力

図 7 は用具・素材の商品について、各店舗における主な購入者を集 計したものである。当然ながら店舗全体の主要顧客層が各商品の主な 購入者になる。しかし、一般消費者利用型店舗であっても建築業者の 購入が多いような、特定の顧客層を誘引する商品が存在する。表 4 は、こうした顧客誘引力の違いに基づき、ホームセンターの取扱商品 を「家庭用資材」「中間資材」「業務用資材」の三つに整理した結果を 示す。

家庭用資材は、どの店舗類型でも一般消費者の購入が多い商品であ る。(5)塗料・塗装具、(6)接着剤・梱包資材は、消費者自身が軽微な補 修を行うための購入と考えられる。建築金物関連では、(4)c)ドア・空 は外部開口部の防犯性や室内ドアの利便性の向上、(4)d)手摺は加齢対 応が購入目的と考えられる。(9)住設機器は水廻りの更新のために購入 されるが、一般消費者自身が設置することは稀であり、ほとんどの場 合、ホームセンターがこうした作業を担当していると思われる。

一方、業務用資材は、どの店舗類型でも建築業者の購入が多い商品 である。これに該当する(4) e) 足場・鋼材等と (7)d) 合板は建築業者の当 用買い対象の典型と考えられる。また、電動工具の(2) $\mathbf{a}$ )業務用は基本 的には建築業者向けの販売であり、DIY を趣味とする一部（以下 DIYer）を除けば一般消費者の購入対象にはならないと考えられる。

中間資材は、どちらの店舗類型でもその主要顧客層が購入する商品 である。合板を除く(7)木質材料とその接合に用いる(4)a)ネジ・釷など が該当する。これらの資材は、一般消費者利用型店舗では DIYer の 購入対象、建設業者利用型店舗では建築業者の当用買い対象になって いると考えられる。

図 8 は中間資材の購入者の増減を示す。一般消費者利用型店舗では どちらの購入者も横ばいであるが、建設業者利用型店舗では両者とも 増加傾向にある。つまり、店舗類型の分析で述べたように、後者の多 くは旗艦店であることから、一般消費者にとっても建築業者にとって も利便性が高いことが窥える。

\section{7. サービス業務の水平展開}

(1) 受注に関するサービス

一般消費者利用型店舗と建築業者利用型店舗の品揃えは基本的に は変わらない。しかし、後者では木質材料等の販売が伸びていること から、物販以外のサービスの充実が予想される。

図 9 は掛売りサービスを示す。店舗全体の $86 \%$ が実施しており、 一般消費者利用型と建築業者利用型とで大きな違いはない。掛売りで は与信管理が必須である。一般的に法人取引では相手に応じて信用枠 を定める。一方、個人に対してはクレジットカードで与信管理を代用 できる。この場合、信用枠は予め決まっているが、特別な審査・手続 きが不要なので少額取引では効用が高い。与信管理にクレジットカー ドを利用する店舗は、建築業者利用型の $42 \%$ を占め、所定の手続き を行えば利用できるものを含めれば $68 \%$ に達する。

図 10 は建築業者からの受注に対寸るサービスを示す。ここでは店 舖類型に応じて明快な違いが見られる。建築業者利用型では、ロット 販売を行う店舗が $70 \%$ 近くに達し、28\%が割引を実施している。一

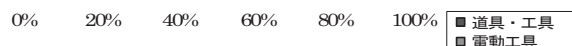

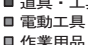
建築金物 口粱料・塗装具

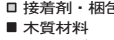
水道・ガス・配管 住設機器・器具

図 6 用具・素材の売上高の内訳

口一般消費者 $\square$ 建築業者 $\square$ 両方

$\begin{array}{llllll}100 \% & 80 \% & 60 \% & 40 \% & 20 \% & 0 \%\end{array}$

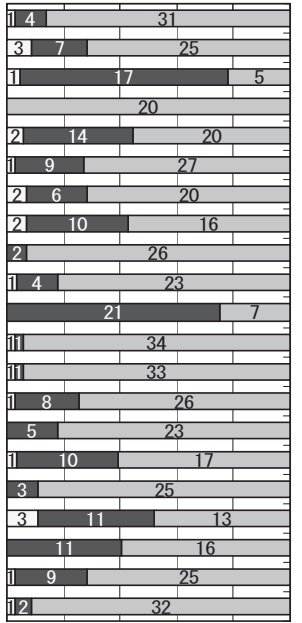

一般消費者利用型店舗 $\begin{array}{llllll}0 \% & 20 \% & 40 \% & 60 \% & 80 \% & 100 \%\end{array}$

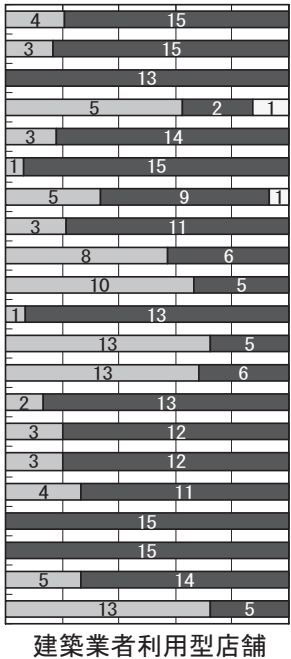

建築業者利用型店舗
図 7 建材別に見た主な購入者

表 4 取扱商品の顧客誘因力

\begin{tabular}{|c|c|c|c|}
\hline & 家庭用資材 & 中間資材 & 業務用資材 \\
\hline 購入者 & 一般消費者 & 店舗の主要顧客層 & 建築業者 \\
\hline 品目 & $\begin{array}{l}\text { (2)b) 一般用電動工具 } \\
\text { (4)c) ドア・空金物 } \\
\text { (4)d) 手摺金物 } \\
\text { (4) f) その他の金物 } \\
\text { (5)塗料・塗装具 } \\
\text { (6)接着剂・梱包材 } \\
\text { (9)住設機器・器具 }\end{array}$ & $\begin{array}{l}\text { (1)道具・工具 } \\
\text { (3)作業用品 } \\
\text { (4)a) ネジ・釘 } \\
\text { (4)b) 建築金物 } \\
\text { (7)a) } 2 \times 4 \text { 材 } \\
\text { (7) b) 木材: 荒材 } \\
\text { (7) c) 集成材 } \\
\text { (7) } \text { 木質ボード } \\
\text { (7) f) その他の木質材料 } \\
\text { (8)水道・ガス・配管 } \\
\end{array}$ & $\begin{array}{l}\text { (2)a) 業務用電動工具 } \\
\text { (4)e) 足場 ・鋼材等 } \\
\text { (7)d) 合板 }\end{array}$ \\
\hline
\end{tabular}

口増加口変化なし 口減少

$\begin{array}{llllllllllll}100 \% & 80 \% & 60 \% & 40 \% & 20 \% & 0 \% & 0 \% & 20 \% & 40 \% & 60 \% & 80 \% & 100 \%\end{array}$

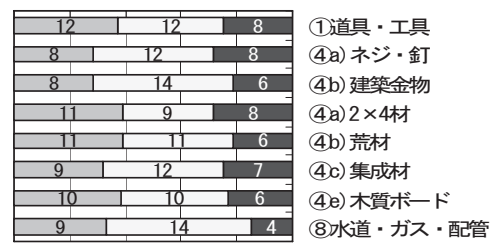

一般消費者

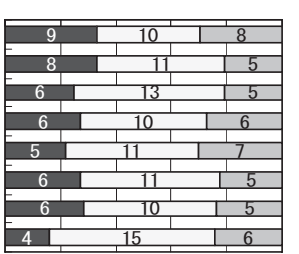

建築業者
(1) 一般消費者利用型店舗

$\begin{array}{llllll}100 \% & 80 \% & 60 \% & 40 \% & 20 \% & 0 \%\end{array}$

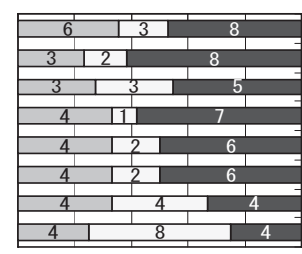

一般消費者 $\begin{array}{llllll}0 \% & 20 \% & 40 \% & 60 \% & 80 \% & 100 \%\end{array}$
(1)道具 $\cdot$ 工具 (4a)ネジ・釘 (4b) 建築金物 (4a) $2 \times 4$ 材 (4b) 荒材 (4c) 集成材 (4e) 木質ボード 8水道・ガス・配管

（2）建築業者利用型店舗

図 8 中間資材の購入者の増減

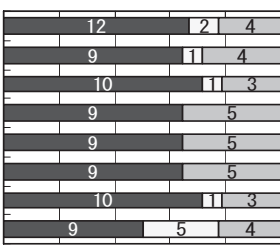

建築業者 
方、こうしたサービスを行う一般消費者利用型店舗はその半分ほどに 過ぎない。また、前者の $64 \%$ が建築業者に対応できる店員を配置し ているのに対し、後者は $23 \%$ に止まる。

\section{(2) 設置・組立に関するサービス}

図 11 は購入品に対する設置・組立サービスを示す。このサービス は一般消費者向けであるが、実施している店舗の割合はむしろ建築業 者利用型の方がやや大きい。基本的にこうした作業は施工業者に外注 されているが、ホームセンター社員が担当する割合は建築業者利用型 の方が大きく、この業務からもこうした店舗に技術力の高い店員が配 置されていることが分かる。

\section{(2) リフォームに関するサービス}

図 12 はリフォームに関するサービスを示す。これも一般消費者向 けであるが、建築業者利用型店舗の方がその本格的なサービス体制が 整っている。建築業者利用型店舗の $67 \%$ はホームセンター自身が請 負契約を結んでいるのに対し、一般消費者利用型店舗の $41 \%$ は提携 業者等への斡旋のみで請負契約の当事者になっていない。

また、リフォーム空口を見ると、担当者がリフォーム業者のみの場 合は $4 \%$ に過ぎないが、ホームセンター社員と共同担当している空口 が $29 \%$ を占める。これらの空口では、リフォーム相談や申込受付と いった実質的業務をリフォーム業者が行うと考えられる。建築業者利 用型の $60 \%$ がリフォーム空口に自社専門スタッフを配置しているの に対し、一般消費者利用型ではその半分ほどに過ぎず、リフォーム業 者が関与する空口が $33 \%$ を占める。

リフォーム工事の対象を見ると、住宅内部だけでなく外構まで含む 店舗が $71 \%$ 占める。住宅内部のみを扱うものは $11 \%$ に過ぎず、外 装改修まで行うものも $17 \%$ に止まる。つまり、ホームセンターのリ フォームサービスは住宅内部と外構の両者を対象としていることが 大きな特徴である。なお、一般消費者利用型店舗と建築工事業者利用 型店舗を比較しても、こうした工事対象の範囲に大きな違いは見られ ない。

\section{8. ホームセンター型建材流通に関する考察}

以上の検討に基づき、ホームセンターの流通チャネルとしての特性 を整理すると次の通りになる。

(1)ホームセンター市場は成長過程にあり、市場分散化も進行してい る。大半の道府県は小売店舗密度が 0.29 ほどに達するが、都市 化の進んだ都府県は、店舗数の飽和に時間を要することから 0.11 付近に止まっており、店舗数増加の余地が残されている。

(2)ホームセンター店舗は主要顧客層の違いから、一般消費者利用型 と建築業者利用型に分けられる。資材館などを併設した店舗を除 けば、両者の品揃えに大差はない。

(3)建築業者利用型店舗の半数ほどは都市近郊の旗艦店であり、これ らの店舗では一般消費者による木質材料等の購入も増加傾向に ある。専門知識の豊かな店員が配置されており、これが一般消費 者に対するリフォームサービスや建築業者に対する物販サービ スの充実に結びついている。

表 5 が示すように、ホームセンター企業は建築業者への建材販売に 積極的である。しかし、建材の大量流通を指向しているわけではない。

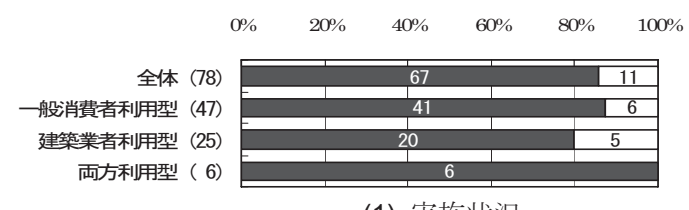

口実施

口未実施

(1) 実施状況

$\begin{array}{llllll}0 \% & 20 \% & 40 \% & 60 \% & 80 \% & 100 \%\end{array}$

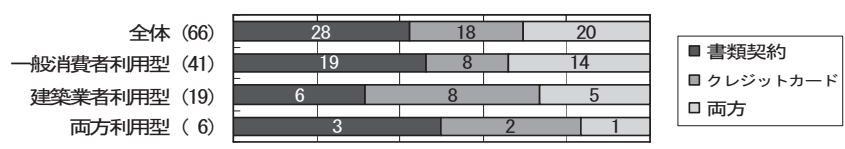

(2) 与信管理の方法

図 9 掛売りサービス

$\begin{array}{llllll}0 \% & 20 \% & 40 \% & 60 \% & 80 \% & 100 \%\end{array}$

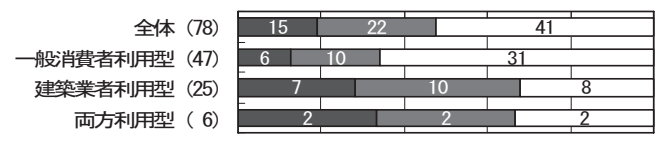

割引有

割引無

(1) ロット販売

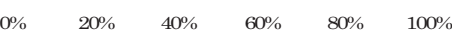

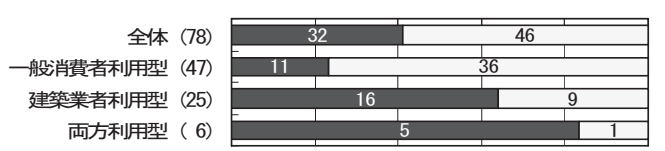

配置

口未配置

(2) 建築業者に対応できる店員の配置

図 10 建築業者からの受注に対するサービス

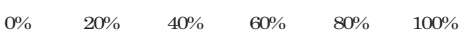

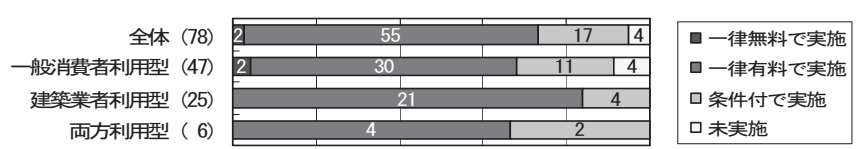

(1) 実施状況

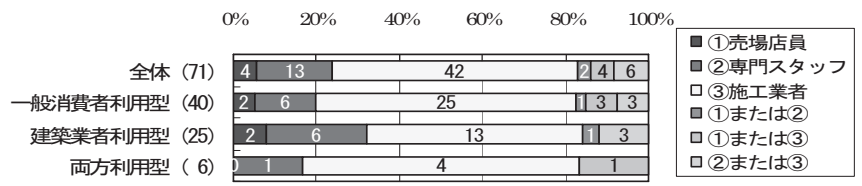

(2) 作業担当者

図 11 設置・組立に関するサービス

$\begin{array}{llllll}0 \% & 20 \% & 40 \% & 60 \% & 80 \% & 100 \%\end{array}$

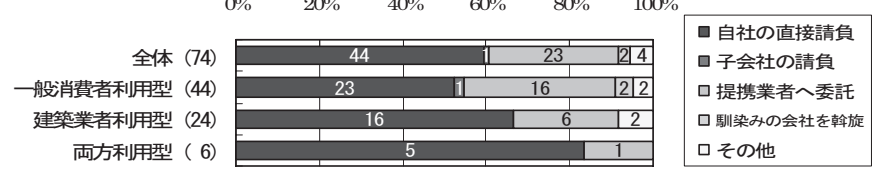

(1) 受注形態

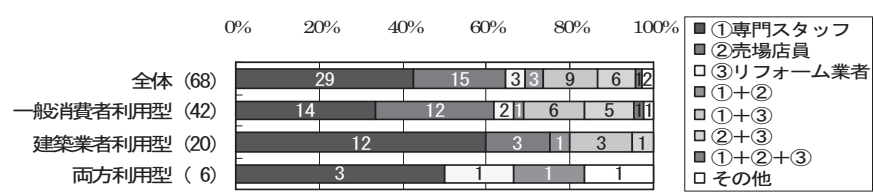

(2) 店頭空口の担当者

$\begin{array}{llllll}0 \% & 20 \% & 40 \% & 60 \% & 80 \% & 100 \%\end{array}$

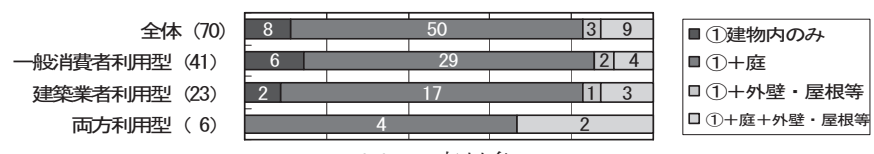

(3) 工事対象

図 12 リフォームに関するサービス 
これらを考慮すると、ホームセンター型建材流通は新築市場よりも住 宅再生市場との適合性が高い。ホームセンターの顧客層の変化は都市 近郊の旗艦店に顕著であり、専門知識豊かな店員が配置されたこれら の店舗では、より高度なサービスが提供され始めている。現在、都市 化の進んだ都府県では店舗当たり半径 $3.6 \mathrm{~km}$ に 9.5 万人の商圈人口 を抱え、それ以外の道府県でも半径 $6.6 \mathrm{~km}$ に 3.5 万人を抱える。前 者に比べて後者の住宅再生市場は低密度であるが、十分な規模を有し ながらも地域的サービスエリアとして適度な範囲に収まっている。

ホームセンターがこうした住宅再生市場の建材流通拠点として展 開していくには二つの方向性がある。その一つは建築業者の小口需要 に向けた建材販売である。この場合、木質材料等の品揃えの拡充が必 要であり、表 5 に示す $\mathrm{A}$ 社・ G 社のように、資材館を併設した店舗も 出現している。しかし、 $\mathrm{E}$ 社が指摘するように、品質管理上の問題か らこうした建材を通常売場に置くことは困難である。従って、建築業 者向けの見本展示を工夫するなど、一般消費者向け販売との両立を検 討する必要がある。

もう一つは住宅再生需要に対する建材・部品の責任施工である。住 宅リフォームには大きな潜在需要が見込まれているが、一方で訪問営 業トラブルも増加しており、信頼できる再生工事業者の出現が待たれ る。ホームセンターは大型小売店舗であるため、各種建材・部品の現 物確認が可能であり、店頭ではこれらの販売価格が明示されることか ら工事価格の透明化にも結びつく。

現在、日本 DIY 協会がリフォーム取扱店として紹介寸る店舗はホ 一ムセンター全体の 1 割程度であり、改修対象も住宅内部と外構に止
まっている。外装改修などを含むホームセンター型リノベーションが 普及寸るためには、地元工務店との提携といった工事体制の整備が必 須である注 20)。こうした業務提携は独力受注が困難になった工務店が 増えていることから双方に利点がある。実際、新築住宅市場には、プ レカット業務を始めた材木店の多くが、こうしたネットワーク形成に よって地域ビルダーに成長していったという先例が存在する。

建築業者向け建材販売にせよ、リノベーション向け責任施工にせよ、 ホームセンター型建材流通が本格化するには店員の建材知識の向上 が共通の課題となる。これまでのホームセンター業界は DIY アドバ イザー資格試験制度によって店員の底上げを図ってきたが、ホームセ ンター社員以外の DIY アドバイザーが累計 6000 人ほどに達する。 こうした人材の多くが既に定年退職していることから、即戦力として リフォーム相談員などに登用寸ることも可能である。今後の居住環境 形成には利用の構想力が重要と考えられるが、こうした DIY アドバ イザーの活用は大きな契機となろう。

また、本社アンケート回答によれば、建築工事業の許可を受けてい る企業は 11 社中 5 社である。ホームセンターが今後の住宅再生市場 において主導的な役割を果たすには、施工技術の力不足が懸念される 状態である。従って、再生工事を地元工務店に委託するとしても、品 質確保のためにはホームセンターが現在以上の現場管理能力を保有 する必要がある。こうした業務の強化については建設会社等を定年退 職した人材の登用が考えられる。つまり、ホームセンター型建材流通 の本格化は、住宅再生に寄与するだけでなく、地域における新たな雇 用創出効果をもたらす可能性も大きいと考えられる。

表 5 ホームセンターに対するヒアリング調査結果

\begin{tabular}{|c|c|c|c|}
\hline & 社所在地 & 店舗数 & \\
\hline & \multicolumn{2}{|c|}{ チェーンエリア } & 建笑番白への的心 \\
\hline \multirow{2}{*}{$\begin{array}{l}\text { A } \\
\text { 社 }\end{array}$} & 大阪府 & 42 店 & \multirow{2}{*}{$\begin{array}{l}\text { 【現状】・主要ターゲット：ノンプロ工事業者 } \\
\cdot \text { 工事業者対策 : 店舗により資材館を併設。プロ用店舗には基本的に日用雑貨は置かない。 } \\
\text { 【今後】・問屋機能を取り込もうという野望はあるが、今のところ场が実現している。 } \\
\end{array}$} \\
\hline & \multicolumn{2}{|c|}{ 関東・近畿等の 14 都府県 } & \\
\hline \multirow{2}{*}{$\begin{array}{l}\mathrm{B} \\
\text { 社 }\end{array}$} & 埼玉県 & 24 店 & \multirow{2}{*}{$\begin{array}{l}\text { 【現状】・主要ターゲット：DIYer } \\
\text { ・事業者対策 : プロ向けに特化しようとは考えていない。 }\end{array}$} \\
\hline & \multicolumn{2}{|c|}{ 埼玉 - 東京・神奈川 } & \\
\hline \multirow{2}{*}{$\begin{array}{l}\mathrm{C} \\
\text { 社 }\end{array}$} & 愛知県 & 8 店 & \multirow{2}{*}{ 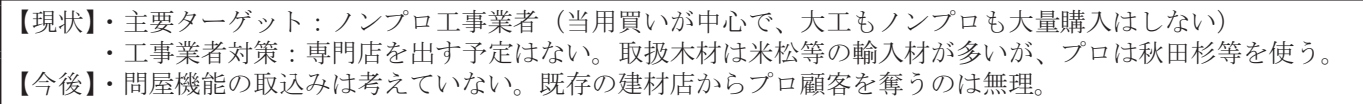 } \\
\hline & \multicolumn{2}{|c|}{ 愛知 } & \\
\hline \multirow{2}{*}{$\begin{array}{l}\mathrm{D} \\
\text { 社 }\end{array}$} & 北海道 & 159 店 & \multirow{2}{*}{ 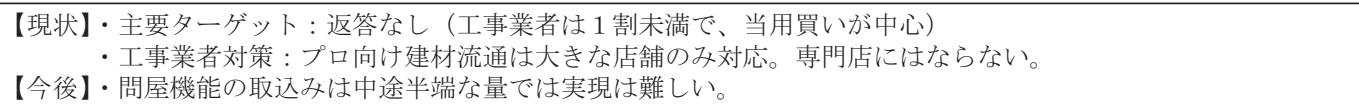 } \\
\hline & \multicolumn{2}{|c|}{ 関東以北の 9 都道県 } & \\
\hline \multirow{2}{*}{$\begin{array}{l}\mathrm{E} \\
\text { 社 }\end{array}$} & 群馬県 & 147 店 & \multirow{2}{*}{ 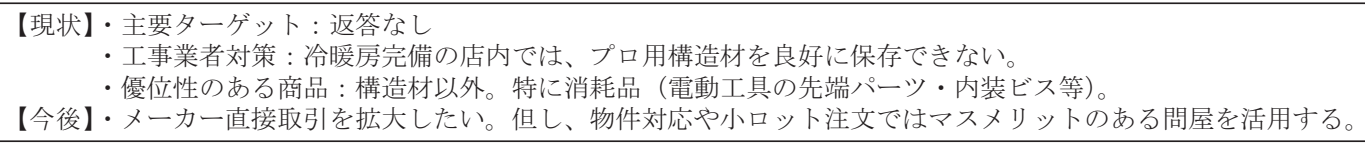 } \\
\hline & \multicolumn{2}{|c|}{ 関東 -中部等の 20 都府県 } & \\
\hline \multirow{2}{*}{$\begin{array}{c}\mathrm{F} \\
\text { 社 }\end{array}$} & 埼玉県 & 77 店 & \multirow{2}{*}{ 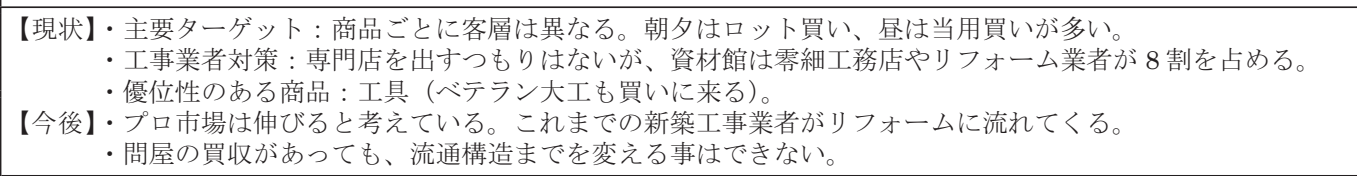 } \\
\hline & \multicolumn{2}{|c|}{ 関東等の 14 都県 } & \\
\hline \multirow{2}{*}{$\begin{array}{l}\mathrm{G} \\
\text { 社 }\end{array}$} & 新潟県 & 763 店 & \multirow{2}{*}{ 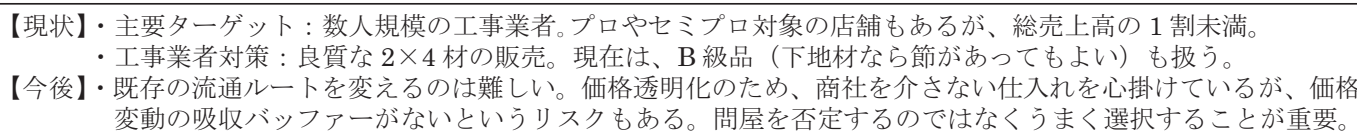 } \\
\hline & \multicolumn{2}{|c|}{ 全国 37 都道府県 } & \\
\hline \multirow{2}{*}{$\begin{array}{l}\mathrm{H} \\
\text { 社 }\end{array}$} & 茨城県 & 23 店 & \multirow{2}{*}{$\begin{array}{l}\text { 【現状】・主要ターゲット：品揃えの } 4 \text { 割は各店舗の事情に合わせて対応。 } \\
\text { ·工事業者対策 : プロ とアア線引きは意識していなが、プロユースにも力を入れている。 } \\
\text { ・優位性のある商品 : 農業用商品 }\end{array}$} \\
\hline & \multicolumn{2}{|c|}{ 茨城・杤木・福島 } & \\
\hline \multirow{2}{*}{$\begin{array}{l}\text { I } \\
\text { 社 }\end{array}$} & 県 & 2 店 & \multirow{2}{*}{$\begin{array}{l}\text { 【現状】・主要ターゲット：工事業者 (ノンプロを含む)。 } \\
\text { DDY 向け商品は専門店で販売。但し、そこでも日用雑貨販売やリフォームサービス等は行っていない。 }\end{array}$} \\
\hline & \multicolumn{2}{|c|}{ 長野 } & \\
\hline
\end{tabular}




\section{9. まとめ}

本報では商業統計やアンケート調査等に基づきホームセンター型 建材流通の検討を行い、取り組むべき課題を整理すると共に今後の住 宅生産に果たしうるその役割を明らかにした。但し、調查過程で浮上 したノンプロ工事業者と呼ばれる新たな業態を明らかにするには至 っていない。今後の建築再生需要の高まりに伴い、こうした業者は産 業として看過できない存在になる可能性があり、その実態把握が課題 として残されている。

\section{参考文献}

1）鈴木安昭・田村正紀，商業論，有斐閣新書，1980.4

2) 経済産業省編, 平成 16 年商業統計表-業態別統計編（小売業），経済産業 統計協会, 2006.3 .

3）社団法人日本 DIY 協会, “社団法人日本 DIY 協会加盟リフォーム取扱い店”, http://www.diy.or.jp/hc_reform/shop.html，（参照 2006.10）。

4）丸山雅祥，日本市場の競争構造，創文社， 1992.7 .

5）成生達彦，流通の経済理論，名古屋大学出版会，1994.12.

6）清水猛，マーケティングと広告研究[増補版]，千倉書房，1988.11.

7）社団法人日本 DIY 協会, “第 18 回 DIY 小売業実態調査報告書 (2006 年度) 抜粋”, http://www.diy.or.jp/members/members/sangyo05.html, （参照 2008.4) .

8）高山卓磨・松村秀一・遠藤和義・角田誠・佐藤考一，“ホームセンターによ る住宅リフォームの現状調査一建築再生における建材流通拠点に関寸る研 究”，日本建築学会大会学術講演梗概集 E-1，pp.1335-1336，2007.8.

注

注 1）本報でいう大型店舗とは、原則として、商業統計の業態分類で「百貨店」 「総合スーパー」「専門スーパー」に含まれる店舗を指す。

注 2）生産と消費の隔たりの 4 要素と厳密に対応するわけではないが、測定可 能な指標としてロットサイズ、市場分散化、配達時間、情報に注目寸る ことが一般的である。1), pp.54-56.

注 3） 2002 年に商業統計の業態分類の見直しが行われ、「住関連スーパー」 が「ホームセンター」と「ホームセンター以外」に細分類された。ホー ムセンター以外の住関連スーパーに含まれる主な業種は、書籍チェーン 店、スポーツ用品チェーン店、楽器チェーン店等である。

なお、本報では商業統計における「ホームセンター以外の住関連スー パー」を「住関連スーパー」と簡略表記する。

注 4）本報で述べる一連の調査は(財)トステム建材産業振興財団の「ホームセ ンターによる建材流通研究」として行った。研究は米澤一幸（トステム ビバ(株)）、栗田紀之・点東航 (A/E WORKS) と共に進め、調査は中 山広樹（東京大学大学院）、小沢宏成・木崎啓太（工学院大学）、北川 玲奈 (東京都立大学) と共同で実施した。なお、これらの所属は調査当 時のものである。

注 5）日本DIY協会のホームページはリフォーム取扱店 541 店舗について「展 示コーナー」「専用受付相談空口」「取次空口」の有無を示している。 これらの中から「取次空口」のみの店舗を調査対象から除外した。3）

なお、調査時点で日本 DIY 協会に加盟する小売業会員は 95 社 3958 店舗である。加盟率は全国のホームセンター経営企業の 3 割ほどである が、年間総売上高の上位 10 社は全て加盟している。これら 10 社は、 2006 年における販売額シェアの $44.1 \%$ 、店舗数の $45.6 \%$ を占める。

注 6）調査期間は 2006 年 10 月〜 12 月である。 8 社はホームセンターの大手 チェーン企業から選定したが、比較のために大規模な金物店 1 社 (I 社) を入れた。調査対象の中の 5 社は 2005 年のホームセンター売上高ラン キング上位 20 社に含まれている。

注 7）いわゆる家電量販店や家具量販店も比較分析の必要がある。店舗規模や 品揃えなどがホームセンターと類似するためである。しかし、これらの 大多数は、非セルフサービス方式のため専門スーパーには含まれず、本 報でいう大型店舗に該当しない。また、商業統計の中では、家電小売店 は「電気機械器具小売業」、家具小売店は「家具小売業」に含まれるが、 こうした業種別集計では売場面積別の内訳は示されていない。そこで、 本報では「従業者 10 人以上の事業所」が専門スーパーの規模要件（売 場面積 $250 \mathrm{~m}^{2}$ 以上）に相当するとみなし、こうした規模の家電小売店 と家具小売店をそれぞれ「家電量販店」と「家具量販店」として扱う。
なお、ホームセンター総売場面積とその内訳の合計值が一致していな いが、これは千 $\mathrm{m}^{2} の$ 位で四捨五入しているためである。

注 8） 1999 年の年間売上総額は、専門スーパーの合計が 23.1 兆円、ホームセ ンターが 2.40 兆円、衣料スーパーが 1.27 兆円である。

注 9）本報では都道府県別に大型店舗の均質な分布を仮定し、店舗当たりの地 域面積の平方根の $1 / 2$ を「商圈半径」とする。なお、商学分野の分析で も均質な小売店舗分布を仮定している。4), pp.30-43. 5), pp.232-244.

注 10） 1), pp.146-147.

注 11）商品分類と買物行動の分析は、1)，pp.108-115、5), pp.51-71.

注 12）立地密度 3 以上（小数点以下四捨五入）の 9 都府県は、東京、神奈川、 大阪、埼玉、愛知、千葉、福岡、香川、茨城である。

注 13）可住地率と宅地率の都道府県平均はそれぞれ $32 \%$ と $\%$ である。

注 14）「民力（朝日新聞社）」に掲載された 50 項目の主成分分析に基づき、47 都道府県を都市化グループ(14) と非都市化グループ(33)に分類した研究 がある。6), pp.169-177, 218.

なお、この研究では北海道、宮城、静岡、滋賀、京都、兵庫を都市化 グループ、香川を非都市化グループに分類しており、これら道府県の扱 いが可住地率と宅地率による整理と異なっている。

注 15）家電量販店と家具量販店の立地密度の回帰直線の他に、参考としてホー ムセンターの回帰直線を立地密度 3 未満と 3 以上に分けて示している。 項目と回帰式の対応は表 3 を参照のこと。

注 16） 1998 年に大規模小売店舗法が撤廃され、大規模小売店舗立地法が施行 された。それまで、大手家電量販企業などは規制対象から外れる店舗(店 舗面積 $500 \mathrm{~m}^{2}$ 末満）を中心に出店してきたが、これを期に出店戦略が 大きく変化している。

注 17）建築業者の中には「ノンプロ工事業者」と通称される業者が含まれる。 その実態は明らかでないが、既存の建材流通チャネルを利用できない零 細な各種専門工事業者、あるいは建築関連業種に属さずにハウスクリー ニング等を行う業者が多いと推察される。

注 18）「DIYアドバイザー」は日本 DIY 協会が認定する資格である。1983 年 に資格試験制度が発足した。2006 年時点で累計資格取得者は約 19,000 名であり、その 7 割をホームセンターの社員が占める。

注 19）日本 DIY 協会が会員に実施する「DIY 小売業実態調査」では総売上高 の内訳を 9 種類に大分類し、さらにその中の「用具・素材」を 9 種類に 中分類する。今回のアンケート調査の売上高に関する設問はこの分類方 法に従っている。なお、2006 年の DIY 小売業実態調査によれば、用具・ 素材が総売上高に占める割合は $22 \%$ でる。7)

注 20）ヒアリング調査を行った全社がリフォーム工事を工務店等に外注して いた。但し、現場管理は自社対応と外注が同数程度である。8)

（2008年 5 月 7 日原稿受理，2008年 7 月 22日採用決定） 